\title{
Perception of the nursing team on pregnancy concerning infection caused by HIV
}

\author{
Percepção da equipe de enfermagem sobre a gravidez no contexto da infecção pelo HIV \\ Percepción del personal de enfermería acerca del embarazo en el contexto de la infección \\ por VIH
}

Marcela Araújo Galdino Caldas ${ }^{1}$, Shyrllene Correia Ferreira Porangaba ${ }^{1}$, Elizabete Santos Melo ${ }^{2}$, Elucir Gir ${ }^{2}$, Renata Karina Reis ${ }^{2}$

Objective: to identify the perception of the nursing team concerning pregnancy in the presence of HIV. Methods: this is a qualitative study made in a reference hospital. For data collection individual interviews were conducted and recorded with 15 nurses who provide care to women during their puerperal and/or pregnancy process. The data were described according to thematic analysis. Results: gestation in the presence of HIV is perceived as irresponsibility, misinformation, and concern with the risks of vertical transmission. The divergent statements of the nursing team point to the lack of understanding of pregnancy in terms of the needs and desires of people living with HIV which may favor an improper procedure and nursing assistance limited to the behavior and technical nursing care in order to reduce vertical transmission of HIV. Conclusion: it is necessary that in the education of health, in the several levels of nursing include matters concerning the gender, sexual and reproductive rights.

Descriptors: Reproductive Rights; Nursing Care; HIV Infections.

Objetivo: conhecer a percepção da equipe de enfermagem acerca da gravidez no contexto da infecção pelo HIV. Método: estudo qualitativo realizado em um hospital de referência. Para coleta de dados, foram realizadas entrevistas individuais e gravadas com 15 profissionais de enfermagem que prestam assistência à mulher durante o seu processo gravídico e/ou puerperal. Os dados foram descritos segundo análise temática. Resultados: a gestação no contexto da infecção pelo HIV/ aids é percebida como irresponsabilidade, desinformação, com preocupação dos riscos da transmissão vertical. Os discursos divergentes da equipe de enfermagem apontam para a falta de compreensão da gravidez no plano das necessidades e desejos de pessoas que vivem com o HIV, o que pode favorecer acolhimento inadequado e assistência de enfermagem limitada a condutas e procedimento técnicos para a redução da transmissão vertical do HIV. Conclusão: é necessário que a formação em saúde nos diversos níveis da enfermagem inclua questões de gênero, direitos sexuais e reprodutivos.

Descritores: Direitos Reprodutivos; Cuidados de Enfermagem; Infecções por HIV.

Objetivo: conocer la percepción del personal de enfermería acerca del embarazo en el contexto de la infección por VIH. Método: estudio cualitativo, realizado en hospital de referencia. Para recolección de datos, se llevaron a cabo entrevistas individuales y grabadas con 15 enfermeros que ofrecían atención a la mujer durante el proceso de embarazo y/o puerperal. Los datos se describieron según el análisis temático. Resultados: la gestación en el contexto del VIH/SIDA se percibe como irresponsable, sin información, con preocupación de los riesgos de la transmisión vertical. Los discursos divergentes del personal de enfermería apuntaron la falta de comprensión del embarazo en el plan de las necesidades y deseos de las personas que viven con VIH, lo que puede favorecer el acogimiento inadecuado y atención de enfermería limitada a conductas y procedimientos técnicos para reducir la transmisión vertical del VIH. Conclusión: es necesario que la formación en salud en todos los niveles de la enfermería incluya cuestiones de género, derechos sexuales y reproductivos.

Descriptores: Derechos Reproductivos; Atención de Enfermería; Infecciones por VIH.

\footnotetext{
${ }^{1}$ Universidade Federal de Alagoas. Maceió, AL, Brazil.

${ }^{2}$ Escola de Enfermagem de Ribeirão Preto, Universidade de São Paulo, SP, Brazil.

Corresponding author: Renata Karina Reis

Av. Bandeirantes, 3900, Campus Universitário Monte Alegre, CEP: 14040-902. Escola de Enfermagem de Ribeirão Preto. Ribeirão Preto, SP, Brazil. E-mail: rkreis@eerp.usp.br
} 


\section{Introduction}

The Acquired Immunodeficiency Syndrome (AIDS) is considered a chronical, treatable condition and it is clinically controlled by the use of medicine ${ }^{(1)}$ which implies in new perspective of life for the people with the Human Immunodeficiency Virus/Acquired Immunodeficiency Syndrome (HIV/AIDS).

Brazil has a growing epidemic, with 686,478 notified cases of AIDS until June, 2013, of those 64.8\% of the male sex and $35.2 \%$ of the female sex. But, in the northeastern region the epidemic has been more expressive, once it presented a rate of $14.8 \%$ notified cases of AIDS in 2012, the largest figure found in the last ten years, when the rate average was 10.3 cases $^{(2)}$.

The rate concerning gender was 1.7 men to one woman in $2013^{(2)}$. Although there are more subjects of male sex in the total of notified cases, in this country the epidemic grows at a higher speed among the women within their reproductive age ${ }^{(3)}$. Besides that, considering the last ten years, the age range of the cases of AIDS changed to younger subjects, both among men as well as among women ${ }^{(2)}$. Such situation promotes the need for the debate on the recognition of the physical, emotional and social needs of the people living with HIV/AIDS.

The possibilities of prevention of vertical transmission of the HIV and procedures of assisted fertilization, which also reduce the risk of transmission, allowed the people who live with the virus to express their desire to have children ${ }^{(4)}$ in a more conscious and safer manner.

Studies evaluated the impact of diagnosis of serum-positivity for the HIV on women, particularly concerning the reproductive decisions ${ }^{(5-7)}$, however, few researches evaluated how the reproductive needs perceived concerning the health services.

The relation between HIV and reproduction/ contraception have emerged as a problem of public health, once the reproductive intentions of people who live with HIV are frequently ignored or not encouraged by people who render health care ${ }^{(4)}$.
So, it is observed that the studies show the unfavorable posture of the health professionals concerning the reproductive matters regarding the infection caused by HIV/AIDS ${ }^{(7)}$. Even in the specialized services of assistance to those people, pregnancy associated to serum-positivity is still perceived as a problem to be faced by the health professionals, who do not consider the possibility of maternity ${ }^{(8)}$.

It is worth highlighting that the people who live with HIV/AIDS have sexual and reproductive rights which must be respected, once they have the right to freely plan whether they want or not to have children, how many and when they are going to have them ${ }^{(9)}$. The right to maternity and paternity is applied to all citizens independently of their HIV serological condition. So, many challenges are still present in the practice of assistance, once the approach of the sexual and reproductive rights by the health professionals to the people who live with HIV/AIDS is still scarce.

So, the role of the health professionals would not be the lack of encouragement to new pregnancies, but help in taking decisions with full knowledge concerning their reproductive health, minimizing the probability of transmission of the mother-child HIV and the infection and reinfection of the partner in the case of choosing pregnancy. However, the guidelines of sexual and reproductive health are not yet effectively implemented in all the health services in the country. Besides that, they find resistance of the health professionals ${ }^{(10)}$.

According to the above mentioned and as a result of the assistance experience at a specialized assistance post, a question emerged as follows: What is the perception of the nursing team on pregnancy concerning the infection caused by HIV/AIDS?

Due to this restlessness associated to the possibility of contributing to the counselling concerning the reproductive decision of the people who live with HIV/AIDS and with the recognition of the physical, emotional and social needs of the family in the puerperal cycle, this study has the objective to know the perception of the nursing team of a reference 
service concerning pregnancy regarding infection caused by HIV/AIDS.

\section{Method}

It is a descriptive study with qualitative approach, made in a public hospital which is a reference in the assistance to pregnant women with HIV/AIDS, located in the capital city of Alagoas, in the northeast of Brazil. This service aims at rendering multidisciplinary assistance to women with HIV/ AIDS, who are in their puerperal cycle, coming from several counties of that State.

In order take part in the study, the health professional should belong to the nursing team of the hospital and has worked in the care rendered to the pregnant woman with HIV/AIDS, for at least six months. It should be highlighted that the nursing team consisted of 59 health professionals, nine were nurses and the other ones were technicians and nursing assistants.

The number of subject was stablished during the interviews, due to the content of their statements, when it was perceived that there was repetition of their speeches, once the sampling was made through data saturation, where the closing of the sample means to define the set which will help the analysis and the interpretation of the data ${ }^{(11)}$. So, 15 health professionals of the nursing team who rendered assistance to the women with HIV/AIDS participated, whether at the pre-partum unit, obstetric center or in the Nursing Rooming.

The data collection was made through individual interviews, face to face, with an average time of 40 minutes, made at the venue of the study, and were obtained from June to August, 2010, guided by an instrument specifically developed for the study, having the following guiding question: What do you think and what is your opinion on pregnancy of women living with HIV/AIDS?

At the time of the interview, it was reported to the participant that she could give up at any time, in case there was a need or she did not want to participate in the study any longer. With her consent, the interview was made. Afterwards, there was the complete transcript. The statements were explored through exhaustive reading of each one of the transcripts individually.

For the treatment of the obtained information, the analysis of content was used, focusing in one of its techniques called thematic analysis, which consists in discovering the nuclei of sense which form communication, whose presence or frequency mean something for the aimed objective ${ }^{(12)}$. The theme is the unit of meaning which is naturally liberated from a text analyzed according to criteria concerning the theory which is used as a guideline to the reading ${ }^{(12)}$.

The thematic analysis consists of three important stages: pre-analysis, exploration of the material and treatment of the results obtained and interpretation $^{(12)}$. In the first stage which covers the organization of the data, there was the brief reading, constitution of the corpus, formulation and reformulation of hypotheses. In this phase the units of context and register, the clippings, the manner of categorization, the modality of codification and the more general theoretical concepts which guided the analysis were stablished.

In the second stage, the exploration of the material was made, in order to find the nucleus of comprehension of the text, represented by categories and subcategories and in the last phase, the data were interpreted.

The project was authorized by the direction of teaching of the hospital under study and approved by the Committee of Ethics in Research of the Universidade Federal de Alagoas (process no. 009367/2009-86). All the participants were informed of the objective of the study, signed the Free Informed Consent Form and agreed to record the interview. For the identification of the several interviews, the name of flowers was used in order to preserve the anonymity of the subject. 


\section{Results}

15 nursing professionals participated in the study, of which seven were nurses, six nursing technicians and two nursing assistants, all of them of the female sex; their age range was between 28 and 52 years. As to the time of working in the assistance to women in their puerperal cycle, it ranged from six months to thirteen years. Regarding the sector of work, it was observed that six were from the prepartum unit, six from the Nursing Rooming and three from the obstetric center.

After the exhaustive analysis of the statements, three categories emerged and they were called: Ambiguity: Pregnancy as an act of irresponsibility $\mathrm{x}$ Right to maternity, Fear of transmission of the HIV to the child and Recognition of the right to have children.

\section{Ambiguity: Pregnancy as an act of irresponsibility $\mathrm{x}$ Right to maternity}

In this category it was identified that despite the statement recognizing as legitimate the right of the women living with HIV/AIDS to get pregnant, a certain ambiguity in the statement was perceived, once the interviewees showed pregnancy as an act of irresponsibility which must not be repeated, according to what is evident, as follows: I personally think it is a lack of responsibility ...it's not taking the right of the woman to have children, but I think like, we've got also to think about the baby, not only about her (Orchid). It makes us sad, to see the lack of responsibility of some patients... I think that everybody has the right to maternity, but many times they knew they have the HIV, they got pregnant because they wanted to (Tulip). At first, we think: why is this woman going to get pregnant if there is the possibility of vertical contamination if she does not have assistance and does not take the prophylactic medication and if she has the baby how is she going to provide assistance? But on the other hand she is a woman who has the right to have a child (Hydrangea).

In these statements the duality between the right to maternity and the limitation which the HIV can bring to the life of the mother-child binomial is evident. The health professionals showed to be conscious as to the right of those women, however they believed that they should think better: I think that should be orientation to provide sterilization and everything else (Daisy). I see this as lack of knowledge, as people who don't have enough culture to see the risk they are facing (Fleur-de-lis). Some are not well informed, but others we know that they are well informed and continue getting pregnant (Rose).

The same way, the health professionals believe that the women got pregnant due to the misinformation on the use of contraceptive methods. For them, the women must have orientation, also for the use of definitive contraceptive methods, such as the sterilization.

\section{Fear of transmission of the HIV to the child}

In this category the reports concerning the risk of mother-child transmission of HIV and the possibility of the children not being brought up by their parents were highlighted as follows: At first we think: Why is this woman going to get pregnant if there is the possibility of vertical contamination, and if she doesn't have assistance and do not take prophylactic medication, and yet she has the baby, how is she going to provide assistance (Hydrangea). I think they should not get pregnant. It is because the child is at risk. I am afraid if is transmitted to the baby, because they do not always take care of themselves the right way (Lilly).

The concern of the health professionals with the risk of transmission of the HIV to the baby is evident. Their position can be related to the responsibility of the epidemic control of the infection caused by the HIV/AIDS and the reduction of the rates of vertical transmission.

\section{Recognition of the right to have children}

In this category, the recognition of the right to maternity of those women, was observed, without judgment, once it emphasizes the right to maternity and consider that the assistance and the adequate treatment can help them to have their children in a 
safer way: It's her option to get pregnant and some people criticize, but who am I to criticize? So, why should we prevent this woman from having children? Once nowadays there are manners of preventing the transmission to the baby, so I don't see why to prevent, once she wants to become a mother (Carnation). We cannot judge nor deprive the patient, I think it is a right, taking all the precautions, following all the treatment and having all the assistance (Lilly).

Under this perspective the health professionals showed to be conscious of the reproductive right of the woman who has the HIV/AIDS, independently of her beliefs or prejudice.

\section{Discussion}

The posture of the professionals, in a general way, showed to be divergent on the reproductive matters, among the women who live with the HIV/ AIDS, some statements recognize the right of these women to have a child, while others presented unfavorable perceptions to pregnancy among women living with the HIV/AIDS. So, pregnancy concerning the infection caused by HIV/AIDS was seen by a large part of the health professionals as related to irresponsibility and misinformation with emphasis in the risks of vertical transmission of the HIV.

Many times, the pregnancy of women with HIV is understood as an act of selfishness, once they should think about the baby, not only about themselves. Besides that, the health professionals highlight the risk for the children to be born serum-positive or without the guarantee of having healthy parents who can assure their future.

These results were also found in a study made in Argentina, where many women who live with HIV reported to have heard pejorative comments and discrimination by part of the health professionals with the intention to make they feel guilty for having gotten pregnant ${ }^{(4)}$.

In the same study, the author states that the health services could assist the reproductive needs of the people who live with HIV in a better way if institutional and cultural obstacles were approached and overcome ${ }^{(4)}$.

Besides that, a national study made in Rio Grande do Sul, Brazil, also confirmed such results, where prejudice and discrimination are also shown by health professionals who have education to work with this population ${ }^{(13)}$.

The women living with HIV/AIDS face the positioning of the health professionals who express their beliefs and values, so that the nursing assistance is permeated by prejudice and stigma. Besides that, the discussion on this theme is, at times, silent as seen in a research made in Spain, where a considerable number of women living with HIV/AIDS reported not receiving any information on their sexual and reproductive rights, even in services of specialized assistance $^{(14)}$.

The statements of the health professionals show the lack of comprehension of pregnancy concerning the needs and desires of the people who live with HIV/AIDS. Such attitude shows to the distinct among these people, once despite the threats resulting from serum-positivity, the pregnancy in the women living with HIV/AIDS is wanted and seen as a compliment of their family lives ${ }^{(7)}$.

A study made in Denmark identified the desire to have children among women who live with HIV is the same desire of the women who do not have HIV/ AIDS, and another one made in Spain reported that the main reason for wanting children were related to the fact they love children and the desire to form a family $^{(14-15)}$.

Besides that, it is common that many women find out they are HIV positive during pre-natal or delivery, but still meet difficulties in this assistance, especially in having complimentary exams, for example the serology. This situation unleashes the postponing of the diagnosis, which is almost never stablished in the first trimester, as it is recommended by the sanitary authorities ${ }^{(7)}$. Such fact can put them under extreme emotional suffering throughout the whole process of diagnosis, thus experiencing feelings of stigmatization, isolation and anxiety. 
So prejudice remains, and many times the woman who lives with HIV/AIDS has unsatisfactory assistance by the health team ${ }^{(16)}$. A study made in Ceará, revealed the lack of humanization of the health professionals in services of reference in health destined to this population, as well as the scarcity of orientations concerning the adequate management for serum-positive patients ${ }^{(16)}$.

Such attitude can contribute, so that the desire of maternity/paternity the context of the infection caused by HIV/AIDS is not shared with the health professionals, even in the services of specialized assistance, which does not provide the adequate discussion and orientations concerning the reproductive matters, which involve the opportune moment of pregnancy and the decrease of the risk and infection/reinfection of the partner.

Besides that, such situation can also project itself in the non-humanized care, which does not assist the psychosocial needs in this unique moment of the life of women living with HIV/AIDS, contributing for the fact that these behaviors are limited to technical procedures which aim at reducing the vertical transmission of the HIV.

In the statement of the nursing team under study, the rejection of the pregnancy in the context of the infection caused by HIV/AIDS is evident, which is confirmed by another study ${ }^{(7)}$. However, women infected by HIV have their reproductive right respected. Furthermore, symbolically, for that woman, having a child means a way to provide continuity to life, which is already marked by a prematurely announced death ${ }^{(16)}$.

As to the risk of vertical transmission of the HIV, it is known that the rate of transmission, which is around $25 \%$ of the newborns of HIV positive pregnant women, when all the interventions are not performed, and it can be reduced to $1 \%$ to $2 \%$ with the implementation of adequate measures during pre-natal and delivery ${ }^{(17)}$. Therefore, with the implementation of all the prophylactic measures recommended, in the last years the incidence of cases of AIDS in children has been progressively decreasing in Brazil ${ }^{(18)}$.

The need to offer treatment of reproduction is highlighted for people who live with HIV/AIDS who want pregnancy, once the risk of associated vertical transmission is reduced after the introduction of the antiretroviral treatment ${ }^{(15)}$.

On the other hand, other diseases can cause risks to health, similar or even bigger, such as eclampsia, maternal and fetal complications associated to diabetes mellitus and despite the high risks of these and other diseases happening during pregnancy, the infection caused by HIV/AIDS is seen as the most negative ones ${ }^{(10)}$. Pregnancy in the context of the HIV is still linked to the idea of disease/morbidity and generates polemics and debate, not only among the health professional, informed by the perspective of risk associated to the modern epidemiology, but also among several other health professionals and sectors of the society who are protagonists in the decisive processes $^{(6)}$, a fact which can delay the availability of a free form of more modern treatment, such as the assisted reproduction.

The infection caused by HIV aggregates some difficulties to the process of maternity, especially the concern with the vertical transmission, the fear or prejudice, the frustration for breastfeeding, the anxiety facing the medicine treatment; however, feeling fulfilled with maternity prevails, the joy facing the growth and healthy development of the baby ${ }^{(19)}$.

The report of little attention of the services for the favorable dialogical relations, and the assistance rendered in this delicate moment in the life of this women is common ${ }^{(16)}$, thus making the desire of having children to be permeated by the conflict and fear of transmission of the HIV for the baby and the partner ${ }^{(8)}$.

So, besides transmitting all the necessary information to a safe puerperal cycle, the health professionals of the specialized centers must inform the opportune time, so that the women living with the HIV/AIDS can get pregnant, based on a meticulous 
evaluation of the clinical and gynecological conditions of the patient, thus observing the reduction of the viral load and the reestablishment of the TCD4 lymphocytes to acceptable levels ${ }^{(19)}$.

The recognition by the health professionals of the right of people living with HIV/AIDS to have children must favor the dialog and the listening of those women, so that, the desire to get pregnant is not experienced in a solitary way ${ }^{(20)}$ and even questioned both by the social experience of the couple as well as by the health team itself.

Even so, around three decades since the discovery of the infection by HIV, it is observed that the impact of this virus in the life of the people of people affected has been modified, as well as their needs. Despite the advancement related to the treatment with antiretroviral medicine, many challenges still persist in the scope of the whole assistance to these patients who face several consequences coming from serum-positivity, regarding to stigma and prejudice, with impact in their social, family, sexual affective and reproductive relations ${ }^{(21)}$.

However, the implementation of public polices which enhance the access to the assistance in the services of attention to health if fundamental and legitimates the right of reproduction of couple living with HIV/AIDS considering the advancement in the area of reproductive health ${ }^{(8)}$.

\section{Final Considerations}

The tendency of feminization of epidemic of HIV/AIDS increases the concern of vertical transmission, which is responsible for around $90 \%$ of the infection of children living with HIV/AIDS. The medicine therapy allied to other procedures has considerably reduced the rate of mother-child transmission. However, in order to reach such result, it is indispensable to have the adequate acting of the health professionals involved in this process.

The divergent statements of the nursing team show the lack of comprehension of pregnancy concerning the needs and desires of the people who live with HIV/AIDS, which can favor an inadequate nursing assistance, limited to behaviors and technical procedures for the reduction of the vertical transmission of the HIV.

It can also be observed that there are feelings of stigma and prejudice concerning the contradiction in the perception of the team regarding the right of the women living with HIV/AIDS to have children.

The concern with the risk of mother-child transmission of HIV is quite highlighted in the statement of the nursing team, even though they know that adopting the measures of intervention for the reduction of the vertical transmission the risk decreases considerably. This perception can many times contribute for the assistance of prejudice nursing as to the right of the women living with HIV/ AIDS to become a mother.

The nursing care provided to the pregnant women must transcend the aspects related to the prevention of the vertical transmission of HIV, and they must also contemplate the emotional and social aspects of living with HIV and being a mother, thus favoring the adaptation of those women to their maternal role, to the care with the newborn and with herself, which requires an interdisciplinary and trained health team in order to assist the need of those women and their families.

Therefore, it is evident that there is the need of reflection of attitudes and practices in the care with health, provided by the nursing team who renders assistance to pregnant women with HIV/AIDS, aiming at the whole and humanized care for the women living with HIV with the puerperal cycle, in order to lessen, as much as possible, the difficulties faced by them, during this peculiar period of their existence.

This study had as main limitation the fact that it was made in only one service of reference of the State which acts in the care to the women in different periods of the puerperal cycle in a northeastern capital city which does not allow the generalization of the data. However, the results reinforce that, despite 
the important advancement obtain in the domain of the public assistance and policies to people living with HIV/AIDS, many challenges still persist, so that the right of this population, especially the female population, are effectively guaranteed in the assistance practice. The whole care to the women concerning their reproductive rights must be guaranteed in all the services of attention to health.

For such, it is necessary that in the education of health in the several levels of nursing include matters concerning the gender, sexual and reproductive rights and integrality in health in the pursuit to develop humanized and above all ethical care, with more widened conceptions of health.

\section{Collaborations}

Caldas MAG, Porangaba SCF and Reis RK contributed for the conception of the work, data collection, analysis, interpretation of the data, writing of the article and final approval of the version to be published. Melo ES and Gir E contributed with the writing of the article and final approval of the version to be published.

\section{References}

1. World Health Organization. Global HIV/AIDS response. Epidemic update and health sector progress towards universal access. Progress Report 2011. Geneva: WHO; 2011.

2. Ministério da Saúde (BR). Secretaria de Vigilância em Saúde. Departamento de DST, Aids e Hepatites Virais. Boletim epidemiológico Aids e DST. Ano II, até a semana epidemiológica $26^{a}$, dezembro de 2013. Brasília: Ministério da Saúde; 2013.

3. Santos NJS, Barbosa RM, Pinho AA, Villela WV, Aidar T, Filipe EMV. Contextos de vulnerabilidade para o HIV entre mulheres brasileiras. Cad Saúde Pública. 2009; 25(supl 2):321-33.
4. Gogna ML, Pecheny MM, Ibarlucia I, Manzelli H, Lopez SB. The reproductive needs and rights of people living with HIV in Argentina: health service users' and providers' perspectives. Soc Sci Med. 2009; 69(6):813-20.

5. Sant'Anna ACC, Seidl EMF. Efeitos da condição sorológica sobre as escolhas reprodutivas de mulheres HIV positivas. Psicol Reflex Crit. 2009; 22(2):244-51.

6. Moás LC, Vargas EP, Maksud I, Britto R. HIV/aids e reprodução: a perspectiva jurídica em análise. Cad Pesqui. 2013; 43(150):948-67.

7. Santos SFF, Bispo Júnior JP. Desejo de ter maternidade entre mulheres com o HIV/aids. Rev Baiana Saúde Pública. 2010; 34(2):299-310.

8. Reis RK, Neves LAS, Gir E. The desire to have children and family planning among hivserodiscordant couples. Ciênc Cuid Saude. 2013; 12(2):210-8.

9. EngenderHealth, Unfpa, organizadores. Saúde sexual e saúde reprodutiva das mulheres adultas, adolescentes e jovens vivendo com HIV e Aids: subsídios para gestores, profissionais de saúde e ativistas. [internet]. 2008 [citado 2014 set 9]. Disponível em: http://www.unfpa.org.br/ Arquivos/saude.pdf

10. Gonçalves TR, Carvalho T, Faria R, Goldim JR, Piccinini CA. Vida reprodutiva de pessoas vivendo com o HIV/aids: revisando a literatura. Psicol Soc. 2009; 21(2):223-32.

11. Fontanella BJB, Luchesi BM, Saidel MGB, Ricas J, Turato ER, Melo DG. Amostragem em pesquisas qualitativas: propostas de procedimentos para constatar saturação teórica. Cad Saúde Pública. 2011; 27(2):389-94.

12. Minayo, MCS. 0 desafio do conhecimento: pesquisa qualitativa em saúde. $12^{\underline{a}}$ ed. São Paulo: HucitecAbrasco; 2010.

13. Machado AG, Padoin SMM, Paula CC, Vieira LB, Carmo DRP. Análise compreensiva dos significados de estar gestante e ter HIV/aids. Rev Rene. 2010; 11(2):79-85. 
14. Hernando V, Alejos B, Álvarez D, Montero M, PérezElías MJ, Blanco JR, Masiá M, et al. Reproductive desire in women with HIV infection in Spain, associated factors and motivations: a mixedmethod study. BMC Pregnancy Childbirth. 2014; 5(14):1-11.

15. Laursen T, Kesmodel US, Hojgaard A, Ostergaard $\mathrm{L}$, Ingerslev HJ, Wejse C. Reproductive patterns and fertility wishes among HIV-infected patients: survey from six outpatient clinics in Denmark. Int J Infect Dis. 2013; 17(10):851-6.

16. Galvão MTG, Cunha GH, Machado MMT. Dilemas e conflitos de ser mãe na vigência do HIV/Aids. Rev Bras Enferm. 2010; 63(3):371-6.

17. Ministério da Saúde (BR). Secretaria de Vigilância em Saúde. Programa Nacional de DST e Aids. Plano Operacional. Redução da Transmissão Vertical do HIV e da Sífilis, Brasil. [Internet]. 2007 [citado 2014 set 09]. Disponível em: http://www. hra.famema.br/nucleo_vigilancia/sifilis2/plano_ operacional_web.pdf
18. Secretaria do Estado da Saúde de São Paulo. Centro de Referência e Treinamento em DST/AIDS. Programa Estadual de DST/Aids, Coordenadoria de Controle de Doenças. Eliminação da transmissão vertical do HIV e da sífilis no Estado de São Paulo. Rev Saúde Pública. 2011; 45(4):812-5.

19. Faria ER, Piccinini CA. Maternidade no contexto do HIV/AIDS: gestação e terceiro mês de vida do bebê. Estud Psicol. 2010; 17(2):147-59.

20. Santos WS, Medeiros M, Munari DB, Oliveira NF, Machado ARM. A gravidez e a maternidade na vida de mulheres após o diagnóstico do HIV/aids. Ciênc Cuid Saúde 2012; 11(2):250-8.

21. Gaspar J, Reis RK, Pereira FMV, Neves LAS, Castrighini CC, Gir E. Quality of life in women with HIV/aids in a municipality in the state of São Paulo. Rev Esc Enferm USP. 2011; 45(1):230-6. 